\title{
A Response to Nothaft on Carabias Torres, Salamanca y la medida del tiempo*
}

\author{
Ana María Carabias Torres \\ Universidad de Salamanca, Spain \\ anacarabias@usal.es
}

As Philipp Nothaft points out in his review, the history and prehistory of the Gregorian calendar reform remains 'a gigantic map with many blank spaces, which also cover most of the Iberian Peninsula'; and indeed, prior to the publication of my book Salamanca y la medida del tiempo, the Iberian Peninsula was mostly covered by such blank spaces. He also credits me with the following contributions [191-193]:

(1) identifying the authors of the 1515 and 1578 Salmantinian reports on calendar reform;

(2) determining the institutional context of these reports (as well as the broader, overarching context), which is difficult to pin down for the year 1515 due to the dearth of documented sources;

(3) the establishment, transcription, and translation of scientific reports from Salamanca in answer to requests from Popes Leo $\mathrm{X}$ and Gregory XIII, and from the Spanish kings Fernando el Católico and Felipe II, as well as the reconstruction of texts in which 16th-century scribes or, in some cases, 19th-century researchers made mistakes when transcribing the original documents;

(4) the facsimile reproduction of ms. 97 from the Biblioteca General Histórica of the University of Salamanca, in so far as 'readers interested in the original Latin [would] greatly appreciate this edition';

(5) the analysis of new manuscript material, such as the report from the University of Alcalá and two explanations of the reform written by the Archbishop of Toledo, García de Loaysa y Girón, and Francisco Salinas, respectively-I was indeed unaware of the Disputatio

* See http://www.ircps.org/aestimatio/10/190-204.

(C) 2013 Institute for Research in Classical Philosophy and Science All rights reserved
ISSN 1549-4497 (online) ISSN 1549-4470 (print) 
de anno... (1468) by Martínez de Osma, which professor Nothaft analyses. This new study reveals that Osma made no worthwhile contributions to solving the problem-and

(6) the use of relevant studies for the history of science in the Iberian Peninsula, some of it rarely accessed by scholars outside the Hispanosphere.

On the other hand, Nothaft objects to the weak arguments that suggest that Lilio could have drawn on the 1515 Salmantinian report. However, as I pointed out [Carabias Torres 2012, 236]:

Es verdad que, analizando la tradición computista desde la Edad Media, cabe pensar que Lilio pudo no haber copiado específicamente el informe salmantino de 1515 -aunque a mí me parece seguro que lo conoció y que en parte copió-, sino que quizá recogió y expuso el contenido y las proposiciones de esta tradición que arranca de Roger Bacon y pasa por Pierre d'Ailly, John de Murs, Fermín de Belleval, Paul von Middelburg, la Universidad de Salamanca, Pedro Ciruelo y seguramente otros.

The fact remains that an analysis of the computist tradition from the Middle Ages onwards suggests that Lilio may not have specifically copied the 1515 Salmantinian report (even though I feel certain that he was aware of its existence and that he copied it in part), and that he might have collected and outlined the contents and propositions of this tradition, which originated with Roger Bacon, followed by Pierre d'Ailly, John of Murs, Firmin of Beauval, Paul of Middelburg, the University of Salamanca, Pedro Ciruelo, and surely others as well.

Why do I feel certain that Lilio knew it and used it? Because only the Salmantinian report of 1515 is missing (or is not where it belongs) in the Vatican archives. Luigi Lilio did not belong to the Vatican commission for calendar reform; and it is, therefore, reasonable to assume that his brother Antonio, who did belong to the commission, faced with the Pope's insistence on implementing the reform as soon as possible, might have lent this document (among others) to his brother, as it was not easy to take a report out of the Vatican archives.

My initial hypothesis that Salamanca contributed decisively to the calendar reform is supported by Nothaft himself when he states that [195]:

from this it should be clear that the only innovation the University of Salamanca could possibly lay claim to would have to concern the intercalation scheme of the Julian calendar, modified so as to reflect the more accurate year-length. 
Specifically, the 1515 Salmantinian report proposed the omission of a bissextile day every 152nd year [Carabias Torres 2012, 300], showing that its authors had performed some uncommonly accurate astronomical calculations. Thus, as I stated, Salamanca provided an important contribution to the Gregorian calendar reform.

The best way of making headway in knowledge is to work first and then to correct and improve the work that has been done. Nothaft has provided us with invaluable data that give nuance to the astronomical question but there is little, I fear, that he could have added to the above-mentioned historical issues 1,2 , and 3 .

Thus, not only do I forgive the youthful vehemence of a foreigner for being a little less sanguine about the result, I also thank him for his meticulous analysis in which he delves further into the participation of the University of Salamanca in the Gregorian calendar reform, a subject that has long been neglected by Spanish and foreign researchers alike. The success of my study is already tangible, as Nothaft has already quoted it tuice and has used its contents once again in his latest publication [see 2013, 522, 543,550]. On the other hand, prior to reading my study, this widely acknowledged expert in Christian chronology was only aware of the chronological studies by two Salmantinians, Alonso de Madrigal and Martínez de Osma [see 2011, 203 ff.], and did not remember the existence of such important manuscripts on the subject as the 'Tabulae ad meridianum Salmantinum', a key work for understanding the level of astrological teachings in Salamanca at the time of Martínez de Osma [Oxford, Bodleian Library, ms. Can. Misc. 27],' or the 'Responsum Academiae Salmanticensis SS.D.N. Gregorio XIII de compendio quoddam et reformatione Kalendarii consulente' [Fuente and Urbino 1855, 20].2

1 Cited in Illuminated manuscripts in the Bodleian Library, Oxford [Pacht and Alexander 1966, 1.69] and commented on in studies by Chabás, García Avilés, and Chaparro.

2 Nothaft was unaware of this despite the fact that there was already reference to it in Gallardo 1863, 1.1087; Kaltenbrunner 1881, 34; the Inventarium codicum latinorum Bibliothecae Vaticanae [Anonymous 1882, № 7049]; Schmid 1882, 395; Picatoste 1891, 67; Fernández Vallín 1893, 220-224; Alonso Getino 1907, 301; Marcos Rodríguez 1931, 299; Muñoz Delgado 1979, 135; Flórez Miguel 1999, 88; and the recent Catálogo de manuscritos de la Biblioteca Universitaria de Salamancaz [Lilao Franca and Castrillo González 1997-2002, 1.96]. 
I am also glad to have contributed to the expansion of his field of research, as his work of 2011 Dating the Passion: The Life of Jesus and the Emergence of Scientific Chronology (200-1600) omits Spanish scientific works on chronology in the 15th and 16th centuries altogether. He failed to mention Abraham Zacut and Jerónimo Muñoz in chapter 7, 'Time for Controversy: Catholic Chronologers and the Date of the Passion in the Fifteenth and Sixteenth Centuries' [2011, 203 ff.]. The Almanach perpetuum (Salamanca, 1469) by Zacut is an invaluable source for his research; the Libro del nueuo cometa y del lugar donde se haze[n] y como se vera por las Parallaxes quan lexos están de tierra y del prognostico deste... by Muñoz (Valencia, 1573) discusses the supernova of 1572, which was also observed by Tycho Brahe. ${ }^{3}$

Fortunately, after reading my book, Nothaft $[2013,531]$ has included information on Abraham Zacut and the 'Tabulae...' by the Salmantinian Professor of Astrology Nicolás Polonio in his latest work, though he still seems to be unaware of the existence of important manuscripts that are relevant to his studies, such as 'Comento o exposición a las crónicas o tiempos de Eusebio' (five vols.) by Tostado in semi-cursive Gothic script with marginal annotations [Biblioteca General Histórica. Salamanca. Mss. 2485-2489]. ${ }^{4}$

It is not always easy for researchers, despite their best efforts, to be aware of all sources; fortunately, however, we can all contribute in order to increase our common knowledge and I am deeply thankful to Professor Nothaft for the instruction that he has provided us in his review.

3 Nothaft 2011 seems unacquainted with the works of Juan de Salaya (translator of Zacuto), Diego de Torres [1485, 1487, ca. 1520], Rodrigo Basurto [1494, ca. 1497], Antonio de Nebrija [ca. 1516], Pedro Margalho [1520], Sancho de Salaya [1536], Juanelo Turriano [1990], Pedro Sánchez Ciruelo [ca. 1515], Hernando de Aguilera [1554], Juan de Arfe y Villafañe [1854], Juan Pérez de Moya [1573], Diego de Zúñiga [1584], the Tractatus Segurae Mathematicae Professoris in universitate complutensi de nova restituendi kalendarium tempore Gregorii XIII [Anonymous 1578], for example. There is more information in Mordechai and Navarro 2006 and Navarro Brotóns 2004.

4 These manuscripts are also cited in Marcos Rodríguez 1957; Keightley 1977; Fernández-Ordóñez 2006 and 2009; Hernández González 1998; Parrilla 2002, 158; the Catálogo de manuscritos de la Biblioteca Universitaria de Salamanca [Lilao Franca and Castrillo González 1997-2002, 2.847], for example. 


\section{BIBLIOGRAPHY}

Alonso Getino, L. G. 1907. Vida y procesos del maestro Fr. Luis de León. Salamanca.

Anonymous. 1578. Tractatus Segurae Mathematicae Professoris in universitate complutensi de nova restituendi kalendarium tempore Gregorii XIII. Vat.Lat. 7048.

_ 1882. Inventarium codicum latinorum Bibliothecae Vaticanae. vol. 7. Rome.

Basurto, R. 1494. Tractatus de natura loci et temporis. Salamanca. ca. 1497. Additamentum ad calendarium Johannis de Monteregio. Salamanca.

Carabias Torres, A. M. 2012. Salamanca y la medida del tiempo. Salamanca.

de Aguilera, H. 1554. Canones astrolabii uniuersalis, secundo aediti autore Doctore Ioanne Aguilera, praefecto aerarii Salmantinae ecclesie \& astrologie publico in eiusdem ciuitatis scholis professor.... Salamanca.

de Arfe y Villafañe, J. 1854. Manual para construir toda especie de relojes de sol...adicionado con un tratado de los relojes de sol horizontales, verticales, laterales, .... Barcelona.

de Madrigal, A. 1506-1507. Tostado sobre el Eusebio. Salamanca.

de Torres, D. 1485. Eclipse del sol. Medicinas preseruativas y curatiuas y remedios contra la pestilencia que significa el eclipse del sol del año de mil cccc.lxxxv a xvi de março. Salamanca.

1487. Astrologicum commentarium. Salamanca. ca.1520. Pronostico o Juyzio nueua y sutilisimamete sacado por Diego de Torres. Salamanca.

de Zúñiga, D. 1584. Didaci a Stunica Salmanticensis eremitae Augustiniani in Iob commentaria quibus triplex eius editi. Toledo.

Fernández-Ordóñez, I. 2006. 'La historiografía medieval como fuente de datos lingüísticos. Tradiciones consolidadas y rupturas necesarias'. Pp. 1779-1808 in Actas del VI Congreso Internacional de Historia de la 
Lengua española II.See http://www.uam.es/personal_pdi/filoyletras/ ifo/publicaciones/13_a.pdf.

Fernández-Ordóñez, I. 2009. 'Manuscritos historiográficos "de autor”. Pp. 91-125 in P. M. Cátedra et al. edd. Los códices literarios de la Edad Media. Interpretación, historia, técnicas y catalogación. San Millán de la Cogolla.

Fernández Vallín, A. 1893. Discursos leídos ante la Real Academia de Ciencias Exactas, Físicas y Naturales en la recepción pública por...Tema. Cultura científica de España en el siglo XVI. Madrid.

Flórez Miguel, C. 1999. 'La ciencia en el siglo de Fray Luis'. In El siglo de Fray Luis de León. Salamanca y el Renacimiento. Catálogo de la exposición. Salamanca.

[Fuente V. and Urbina, J.] 1855. Catálogo de los libros manuscritos que se conservan en Biblioteca de la Universidad de Salamanca. Formado y publicado de órden del señor Rector de la misma. Salamanca.

Gallardo, B. J. 1863-1889. Ensayo de una biblioteca de libros raros y curiosos. Madrid.

Hernández González, M. I. 1988. ‘A vueltas con Alfonso Fernández de Madrigal y el Marqués de Santillana. De traducciones y comentos'. Pp. 72-105 in M. I. Hernández González ed. En la teoría y en la práctica de la traducción. La experiencia de los traductores castellanos a la luz de sus textos (siglos XIV y XVI). Salamanca.

Kaltenbrunner, F. 1881. 'Beiträge zur Geschichte der Gregorianischen Kalenderreform: I. Die Commission unter Gregor XIII nach Handschriften der Vaticanischen Bibliotek'. Sitzungsberichte der Philosophisch-Historische Classe, der Kaiserlichen Akademie der Wissenschaften 97:7-54.

Keightley, R. G. 1977. 'Alfonso de Madrigal and the Chronici Canones of Eusebius'. Journal of Medieval and Renaissance Studies 7:225-258.

Lilao Franca, O. and Castrillo González, C. 1997-2002. Catálogo de manuscritos de Biblioteca Universitaria de Salamanca. Salamanca. 
Marcos Rodríguez, F. 1931. 'Notas para la historia de la astronomía en la España medieval'. Pp. 391-396 in Revista de la Academia de Ciencias Exactas.

1957. 'Los manuscritos de Alfonso de Madrigal conservados en la Biblioteca Universitaria de Salamanca'. Salmanticensis 4:1-50.

Margalho, P. 1520. Phisices compendium. Salamanca.

Mordechai, F. and Navarro, V. 2006. Universities and Science in the Early Modern Period. Dordrecht.

Muñoz Delgado, V. 1979. 'Ciencia y filosofía de la naturaleza en la península ibérica, 1450-1600'. Repertorio de Historia de las Ciencias Eclesiásticas en España 7:67-151.

Navarro Brotóns, V. 2004. Jerónimo Muñoz. Introducción a la astronomía y a la geografía. Valencia.

Nebrija, A. de C. 1516. Tabla de la diversidad de los días y horas. Alcalá de Henares.

Nothaft, C. P. E. 2011. Dating the Passion: The Life of Jesus and the Emergence of Scientific Chronology (200-1600). Leiden.

_ 2013. 'Reforming the Calendar at the University of Salamanca ca. 1468: Pedro Martínez de Osma and his Disputatio de anno...'.eHumanista 23:522-556.

Pacht, O. and Alexander, J. J. G. 1966-1973. edd. Illuminated Manuscripts in the Bodleian Library, Oxford. 3 vols. Oxford.

Parrilla, C. 2002. 'Alfonso Fernández de Madrigal, el Tostado'. Pp. 157-160 in C. M. Carlos Alvar ed. Diccionario filológico. Madrid.

Pérez de Moya, J. 1573. Tratado de cosas de astronomia y cosmographia y philosophia natural.... Alcalá.

Picatoste, F. 1891. Apuntes para una biblioteca científica española del siglo XVI. Estudios biográficos y bibliográficos de ciencias exactas físicas y naturales y sus inmediatas aplicaciones en dicho siglo. Madrid.

Salaya, S. 1536. Repertorio de los tiempos. Zaragoza. 
Sánchez Ciruelo, P. ca. 1515. De correctione kalendarii. In Expositio libri missalis peregregi.... Alcalá.

Schmid, J. 1882. 'Zur Geschichte der Gregorianischen Kalenderreform: I. Die der Reform vorausgehenden und unmittelbar folgenden wissenschaftlichen Arbeiten'. Historisches Jahrbuch der Görres-Gesellschaft 3:388-415.

Turriano, J. 1990. Breve discurso a su majestad el rey católico en torno a la reducción del año y reforma del calendario con la explicación de los instrumentos inventados para enseñar su uso en la práctica Juanelo Turriano, con una introducción de José A. García, y un análisis del códice por José María González Aboin, así como el manuscrito inédito, en su idioma original y traducción al castellano. Madrid. 